\title{
Microbial Community Structures of Novel Icelandic Hot Spring Systems Revealed by PhyloChip G3 Analysis
}

\author{
Jordan E. Krebs, ${ }^{1, \star}$ Parag Vaishampayan,, ${ }^{1, \star}$ Alexander J. Probst, ${ }^{2, \star}$ Lauren M. Tom, ${ }^{3}$ \\ Viggó Thór Marteinsson, ${ }^{4}$ Gary L. Andersen, ${ }^{3}$ and Kasthuri Venkateswaran ${ }^{1}$
}

\begin{abstract}
Microbial community profiles of recently formed hot spring systems ranging in temperatures from $57^{\circ} \mathrm{C}$ to $100^{\circ} \mathrm{C}$ and $\mathrm{pH}$ values from 2 to 4 in Hveragerði (Iceland) were analyzed with PhyloChip G3 technology. In total, 1173 bacterial operational taxonomic units (OTUs) spanning 576 subfamilies and 38 archaeal OTUs covering 32 subfamilies were observed. As expected, the hyperthermophilic $\left(\sim 100^{\circ} \mathrm{C}\right)$ spring system exhibited both low microbial biomass and diversity when compared to thermophilic $\left(\sim 60^{\circ} \mathrm{C}\right)$ springs. Ordination analysis revealed distinct bacterial and archaeal diversity in geographically distinct hot springs. Slight variations in temperature (from $57^{\circ} \mathrm{C}$ to $64^{\circ} \mathrm{C}$ ) within the interconnected pools led to a marked fluctuation in microbial abundance and diversity. Correlation and PERMANOVA tests provided evidence that temperature was the key environmental factor responsible for microbial community dynamics, while $\mathrm{pH}, \mathrm{H}_{2} \mathrm{~S}$, and $\mathrm{SO}_{2}$ influenced the abundance of specific microbial groups. When archaeal community composition was analyzed, the majority of detected OTUs correlated negatively with temperature, and few correlated positively with $\mathrm{pH}$. Key Words: Microbial diversity—PhyloChip G3-Acidophilic_-Thermophilic_Hot springs-Iceland. Astrobiology $14, \mathrm{xxx}-\mathrm{xxx}$.
\end{abstract}

\section{Introduction}

$\mathbf{M}$ OLECULAR TECHNIQUES continuously widen the scope of microbial diversity studies and initiate fundamental biological research of extreme terrestrial environments, the most common of which are hot springs (Hugenholtz et al., 1998; Kanokratana et al., 2004), solfatara (Kvist et al., 2007), hydrothermal vents (Martin et al., 2008), and geothermally heated soils (Marteinsson et al., 2001a). Thermophilic and hyperthermophilic microorganisms are of particular interest to microbiologists searching for bioactive compounds as well as hot spring habitats to examine molecular or mineral evidence of ancestral extremophiles. Typically, these hot springs contain fluids laden with dissolved mineral ions, which precipitate and create mineral deposits. With temperatures reaching above $100^{\circ} \mathrm{C}$, Icelandic hot springs are some of the hottest in the world and are therefore ideal for studying microbial life under extreme conditions (Barth, 1950).
Due to their characteristic overall low biomass, exploring hot spring ecosystems with conventional methods is challenging. Prior to developments in molecular techniques, cultivation assays and microscopy were employed to study thermal spring systems (Shivvers and Brock, 1973; Shima and Suzuki, 1993). Although these techniques have advanced our understanding of life in extremes (see Stetter, 1982; Stetter et al., 1981), they prove inadequate when discerning microbial community structure and interaction (Blank et al., 2002; Mori et al., 2008; Kublanov et al., 2009). Since the 1990s, molecular methods such as ribosomal ribonucleic acid (rRNA) gene sequencing via radiolabeling have been used to examine terrestrial hot spring microbial communities (Stahl et al., 1985; Ward et al., 1990). This approach, along with subsequent conventional cloning and Sanger sequencing, has led to the discovery of novel uncultivated hyperthermophilic microorganisms (Reysenbach et al., 1994; Barns et al., 1996; Pace, 1997).

DNA microarray approaches like the PhyloChip have been demonstrated to accurately measure microbial community

\footnotetext{
${ }^{1}$ Biotechnology and Planetary Protection Group, Jet Propulsion Laboratory, California Institute of Technology, Pasadena, California, USA.

${ }^{2}$ Institute for Microbiology and Archaea Center, University of Regensburg, Regensburg, Germany.

${ }^{3}$ Ecology Department, Earth Sciences Division, Lawrence Berkeley National Laboratory, Berkeley, California, USA.

${ }^{4}$ Matis ohf. Food Safety, Environment and Genetics, Reykjavik, Iceland.

*Contributed equally.
} 
composition in extremely low biomass samples, such as those found in spacecraft assembly clean rooms (Cooper et al., 2011; Venkateswaran et al., 2012). As PhyloChip analysis can detect the presence of rare microorganisms at a proportional fraction of less than $10^{-4}$ abundance compared to the total sample, it can be used to measure microbial community structures in various environments (Brodie et al., 2006; La Duc et al., 2009; Hazen et al., 2010). Furthermore, it was documented that even the earlier second-generation (G2) PhyloChip offered better bacterial and archaeal diversity coverage depth than short read pyrosequencing ( 243 bp) when applied to acidophilic $(\mathrm{pH} 2.7)$ and mesophilic $\left(29^{\circ} \mathrm{C}\right)$ spring samples from the Colombian Andes (Bohorquez et al., 2012). The third-generation (G3) PhyloChip employed in this study implements more than 1 million probes targeting over 59,000 bacterial and archaeal $16 \mathrm{~S}$ rRNA genes (DeSantis et al., 2007; Hazen et al., 2010).

The molecular microbial community structure of neutral $\mathrm{pH}$ hot springs has been assessed in Iceland (Skírnisdóttir et al., 2000; Marteinsson et al., 2001a), Thailand (Kanokratana et al., 2004), and other parts of the world (Tobler and Benning, 2011), as have acidophilic (pH 2.7) and mesophilic $\left(29^{\circ} \mathrm{C}\right)$ springs in the Colombian Andes (Bohorquez et al., 2012). However, to our knowledge, this study is the first attempt to elucidate the molecular microbial community structure of an extremely low biomass, acidophilic ( $\mathrm{pH} 2-4)$, and hyperthermophilic $\left(55-100^{\circ} \mathrm{C}\right)$ Icelandic hot spring system with a highly sensitive microarray technology. In addition, we measured total and viable microbial populations, using field-deployable rapid molecular assays that enabled the in situ estimation of microbial burden. Furthermore, this study compared the influence of various parameters on the presence and prevalence of community structure.

\section{Materials and Methods}

\subsection{Field sites and sample collection}

Samples were collected from three Icelandic hot springs in the same geothermal vent field in Hveragerði, Iceland, $45 \mathrm{~km}$ southeast of Reykjavík. The surrounding active geothermal area is part of the Hengill central volcano, which experiences frequent minor earthquakes. The hot spring system, which is approximately $20 \mathrm{~m}$ long, includes three interconnected pools (P1, P2, and P3). A fourth pool (P0) at the beginning of the system, with no surface connection to the other three, was used as the control site (Fig. 1). In addition, two other geographically distinct hot springs were sampled: Leirgerdur (L1) ( 250 m northeast of P0) and the vegetated Hrifla spring (HS1) ( 330 m northeast of P0; Fig. 1). The distance between L1 and HS1 is $\sim 125 \mathrm{~m}$.

\subsection{Physical and chemical parameters measurement}

The geographic location, physical and chemical characteristics of the hot spring systems examined during this study have already been described (Marteinsson et al., 2013) and were used to interpret each parameter's influence on the abundance of microbial richness. Temperature was measured with an in situ probe developed by ISOR, Iceland Geo Survey, and ionic activity was measured with a $\mathrm{pH}$ meter (PHM220, Radiometer, Copenhagen, Denmark). The EGM-1 (by PP Systems, Hitchin, UK) device was used to
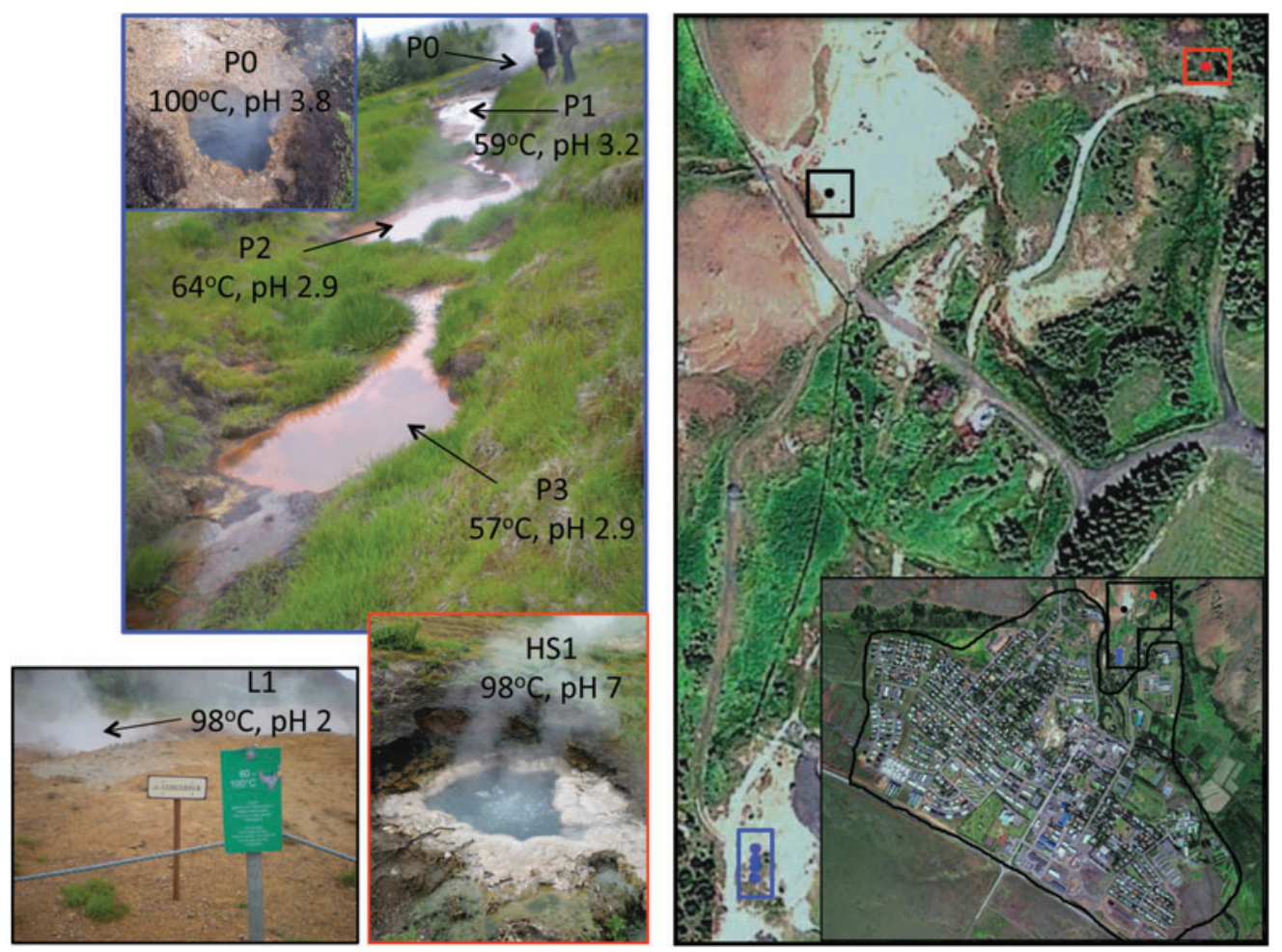

FIG. 1. Hot spring sampling sites of Hveragerði, Iceland. Borders of hot spring images correspond to the representative colored dots on the map to the right. Inset map shows outlined sampling location in reference to outlined Hveragerði town. 
detect $\mathrm{CO}_{2}$ (in ppm) through infrared analysis. $\mathrm{SO}_{2}$ and $\mathrm{H}_{2} \mathrm{~S}$ concentrations were measured with an APSA 370 monitor (HORIBA, Kyoto, Japan). These measurements were carried out in two zones: the area directly associated with the hot springs (P1, P2, and P3 locations) and at a $20 \mathrm{~m}$ distance from the hot spring (P0) as the control site.

\subsection{Sample characteristics}

The physical, chemical, and microbiological characteristics of the Icelandic hot spring samples collected during this study are summarized in Table 1. The color of the three interconnected hot spring pools (P1, P2, and P3) and L1 was brick red, but the P0 hot spring was grayish-black in color. The HS1 hot spring was colorless with a neutral $\mathrm{pH}$ and high temperature $\left(98^{\circ} \mathrm{C}\right)$. Likewise, the highly acidic L1 ( $\mathrm{pH} 2)$ and $\mathrm{PO}(\mathrm{pH} 3.8)$ pools had high temperatures recorded at $98^{\circ} \mathrm{C}$ and $100^{\circ} \mathrm{C}$, respectively. However, the other three interconnected acidic hot spring pools ( $\mathrm{P} 1$, P2, and P3) had comparatively low temperatures (57$\left.64^{\circ} \mathrm{C}\right)$. The temperature of the $\mathrm{P} 2$ hot spring pool was higher $\left(64^{\circ} \mathrm{C}\right)$ than the adjacent hot spring pools (P1 and P3) due to having submerged hot water outlets. The location of L1 was unique in that there was no surrounding vegetation, while the HS1 spring was insulated from the surrounding vegetation by a basin $(>20 \mathrm{~cm}$ in diameter) of silica precipitation (Fig. 1).

\subsection{Sample processing}

All samples were aseptically collected in sterile containers and disposables. A matrix of surface water slurry $(50 \mathrm{~mL}$ of semiliquid mixture of a thin sloppy mud) and solid mud $(50 \mathrm{~g})$ was collected in triplicate from each sampling site.
Slurry samples were collected with a sterile pipette and mud samples with a sterile scoop with a maximum depth of $25 \mathrm{~cm}$ deep into the sediment. The samples were then transported from the hot springs site to a hotel room in a cooling box at $4^{\circ} \mathrm{C}$. The table surface used as a makeshift laboratory was cleaned with sterile $70 \%$ ethanol before sample processing in the hotel room. In total, six samples in triplicate were collected: four from hot spring pools (P0, P1, P2, and P3), one from the Leirgerdur (L1) hot spring, and one from the Hrifla spring (HS1). Appropriate controls were added to downstream molecular microbiological assays to ensure the cleanliness of the makeshift laboratory. By using a handheld adenosine triphosphate (ATP) instrument (Lumitester PD-10 and Lucipac-W, Kikkoman, Tokyo, Japan), in situ ATP measurements of the samples were carried out (data not shown). This approach enabled the selection of samples with measurable biomass. Furthermore, all collected samples were subjected to a high sensitivity ATP assay (see below) within $2 \mathrm{~h}$ of sampling in a makeshift laboratory near the sampling site before refrigeration or freezing. All samples were then transported to the Jet Propulsion Laboratory for further molecular analyses.

\subsection{ATP assay}

A bioluminescence assay was performed on all samples by using the CheckLite HS kit (Kikkoman) to determine the total ATP and intracellular ATP, as described previously (Venkateswaran et al., 2003). To determine the total ATP (dead and viable microbes), $0.1 \mathrm{~mL}$ sample aliquots (four replicates; slurries) were combined with $0.1 \mathrm{~mL}$ of a cell lysing detergent (benzalkonium chloride) then incubated at room temperature for $1 \mathrm{~min}$ prior to adding $0.1 \mathrm{~mL}$ of

Table 1. Characteristics of the Six Hot Spring Sampling Sites of the Hveragerdi, Iceland

\begin{tabular}{|c|c|c|c|c|c|c|}
\hline Parameters & $P O$ & P1 & $P 2$ & $P 3$ & L1 & $H S 1$ \\
\hline Physical state & Mud & Slurry & Slurry & Slurry & Mud & Liquid \\
\hline Color & Gray/black & Brick red & Brick red & Brick red & Brick red & Colorless \\
\hline Temperature $\left({ }^{\circ} \mathrm{C}\right)$ & 100 & 59 & 64 & 57 & 98 & 98 \\
\hline $\mathrm{pH}$ & 3.8 & 3.2 & 2.9 & 2.9 & 2.0 & 7.0 \\
\hline $\mathrm{SO}_{2}(\mathrm{ppm})^{\mathrm{a}}$ & $1.1 \times 10^{-2}$ & $3.4 \times 10^{-3}$ & $3.6 \times 10^{-3}$ & $3.6 \times 10^{-3}$ & $\mathrm{ND}^{\mathrm{b}}$ & ND \\
\hline $\mathrm{H}_{2} \mathrm{~S}(\mathrm{ppm})^{\mathrm{a}}$ & $1.8 \times 10^{0}$ & $4.9 \times 10^{-1}$ & $1.4 \times 10^{-2}$ & $1.4 \times 10^{-2}$ & ND & ND \\
\hline $\mathrm{CO}_{2}(\mathrm{ppm})^{\mathrm{a}}$ & $3.996 \times 10^{2}$ & $3.902 \times 10^{2}$ & $3.887 \times 10^{2}$ & ND & ND & ND \\
\hline Presence of vegetation around & Yes & Yes & Yes & Yes & No & Yes \\
\hline Total microbial population (RLU/mL) & $\mathrm{BDL}^{\mathrm{c}}$ & $2.9 \times 10^{6}$ & $1.5 \times 10^{6}$ & $2.7 \times 10^{6}$ & $1.2 \times 10^{6}$ & $5.3 \times 10^{4}$ \\
\hline Total viable microbial population (RLU/mL) & BDL & $4.0 \times 10^{5}$ & $1.4 \times 10^{6}$ & $1.0 \times 10^{4}$ & $1.4 \times 10^{5}$ & $3.7 \times 10^{3}$ \\
\hline Percent viable microbial population ${ }^{\mathrm{d}}$ & $-{ }^{\mathrm{e}}$ & 14.1 & 94.8 & 0.4 & 12.2 & 7.0 \\
\hline $\begin{array}{l}\text { Total bacterial population (16S rRNA } \\
\text { copy number/mL) }\end{array}$ & BDL & $1.0 \times 10^{6}$ & $2.8 \times 10^{4}$ & $4.0 \times 10^{5}$ & $3.4 \times 10^{4}$ & $8.7 \times 10^{2}$ \\
\hline Percent total bacterial population ${ }^{\mathrm{f}}$ & - & 37.3 & 1.8 & 14.8 & 2.9 & 1.6 \\
\hline Bacterial PCR amplification $(\mathrm{ng} / \mu \mathrm{L})$ & BDL & 117.06 & 81.51 & 117.86 & BDL & BDL \\
\hline Archaeal PCR amplification $(\mathrm{ng} / \mu \mathrm{L})$ & BDL & 189.75 & 70.9 & 88.38 & 28.97 & BDL \\
\hline Bacterial subfamilies detected & 8 & 313 & 127 & 318 & 7 & 8 \\
\hline Archaeal subfamilies detected & 0 & 16 & 10 & 18 & 4 & 2 \\
\hline
\end{tabular}

${ }^{\mathrm{a}}$ Data from Marteinsson et al., 2013.

${ }^{\mathrm{b}} \mathrm{ND}$ : Not determined.

${ }^{\mathrm{c} B D L}$ : Below detection limit.

${ }^{\mathrm{d}}$ Percent viable microbial population was calculated as (Internal ATP/Total ATP) $\times 100$

${ }^{\text {e}}$ Percent viable microbial population was not determined, as both total microbial (Total ATP) and total viable microbial (Internal ATP) populations were below the detection limit. Percent total bacterial population was not determined, as total microbial population (Total ATP) and total bacterial population (bacterial qPCR) were below the detection limit.

${ }^{\mathrm{f}}$ Percent total bacterial population was calculated as $(16 \mathrm{~S}$ rRNA copy numbers measured via bacterial qPCR/Total ATP $) \times 100$. 
luciferin-luciferase reagent. The sample was mixed, and the resulting bioluminescence was measured with a luminometer (Kikkoman). To determine the intracellular ATP (viable microbes), $0.1 \mathrm{~mL}$ of an ATP-eliminating reagent (apyrase, adenosine deaminase) was added to a $1 \mathrm{~mL}$ portion of the sample, mixed, and incubated for $30 \mathrm{~min}$ to remove any extracellular ATP, after which the ATP assay was carried out as described above. As previously established, one relative light unit (RLU), the unit of measurement of ATP, was assumed to be approximately equal to one colonyforming unit (La Duc et al., 2007).

\section{6. $q P C R$ assay}

The frozen mud/slurries were thawed at room temperature, and $1 \mathrm{~mL}$ of subsample was aseptically transferred for DNA extraction. Nucleic acid from each sample was extracted in duplicate with a PowerSoil DNA Isolation Kit (Catalogue \# 12888, MoBio Lab, Carlsbad, CA, USA) by using the manufacturer's protocol. A real-time quantitative polymerase chain reaction ( $\mathrm{qPCR}$ ) assay targeting the 16S rRNA gene was performed in triplicate with a qPCR instrument (BioRad CFX-9600, Hercules, CA, USA) to measure bacterial burden. Standards were prepared from known concentrations of PCR amplicon of the 16S rRNA gene from Escherichia coli spanning $10^{8}$ to $10^{2}$ gene copies/ $\mu \mathrm{L}$. Universal bacterial primers targeting the $16 \mathrm{~S}$ rRNA gene, $1369 \mathrm{~F}$ (5'-CGG TGA ATACGT TCY CGG-3'), and modified 1492R (5'-GGW TAC CTTGTT ACG ACT T-3') were used for this analysis (Kwan et al., 2011).

\subsection{PhyloChip G3 analysis}

Bacterial and archaeal 16S rRNA genes were amplified from DNA preparations of each sample. When having quantifiable DNA concentrations for P1, P2, and P3 (Qubit 1.0, Invitrogen, Grand Island, NY, USA), $3.0 \mathrm{ng}$ of DNA was used per PCR reaction and amplified in eight replicate $25 \mu \mathrm{L}$ reactions spanning a temperature gradient of 48$58^{\circ} \mathrm{C}$, as previously described (Hazen et al., 2010). For lowbiomass samples irrespective of DNA concentration (Table 1), $4 \mu \mathrm{L}$ of DNA was used for gradient PCR reactions. Archaeal amplification of 16S rRNA genes was performed with primers $4 \mathrm{Fa}$ and $1492 \mathrm{R}$; bacterial amplicons were generated by using the $27 \mathrm{~F}$ and $1492 \mathrm{R}$ primer pair (Hazen et al., 2010). A total of $35 \mathrm{PCR}$ reaction cycles was run for each gradient PCR. Bacterial PCR amplicon was concentrated to $\sim 25 \mu \mathrm{L}$ with Amicon Ultra- $0.5 \mathrm{~mL}$ Centrifugal Filters (Millipore, Billerica, MA, USA). Archaeal PCR amplicon was concentrated as above, gel-extracted with the Qiagen MinElute Gel Extraction Kit (Qiagen, Valencia, CA, USA), and eluted in $15 \mu \mathrm{L}$ of elution buffer. Subsequently, $1 \mu \mathrm{L}$ of concentrated bacterial and archaeal amplicons were quantified by $2 \%$ agarose gel (Invitrogen, Carlsbad, CA, USA) prior to running PhyloChips. A maximum of $600 \mathrm{ng}$ of PCR amplicon (500 ng bacterial and $100 \mathrm{ng}$ archaeal) from each sample was used for PhyloChip analysis. However, when the bacterial PCR amplicon concentration was below $500 \mathrm{ng}$ per a volume of $21.5 \mu \mathrm{L}$, a maximum of $21.5 \mu \mathrm{L}$ of the PCR amplicons was used. A detailed explanation of the PhyloChip G3 assay and operational taxonomic unit (OTU) calling has been described elsewhere (DeSantis et al., 2007; Hazen et al., 2010). The OTU analysis is referred to as "microbial richness or diversity" in this communication. Hybridization intensities of OTUs were transformed $\left(\log _{2} *\right.$ 1000) and are henceforth referred to as "microbial abundance."

\subsection{PhyloChip data processing and statistical analysis}

Ordination analysis (non-metric multidimensional scaling, NMDS) and PERMANOVA testing (at 999 permutations), based on abundance scores of OTUs and a Bray-Curtis distance, were performed in the $\mathrm{R}$ programming environment (Vegan and MASS package). Weighted principal component analysis (PCoA) was performed by using the FAST Unifrac interface in which OTUs were grouped into subfamilies and the number of different OTUs per subfamily served as weighting (Hamady et al., 2010).

Pearson correlation of microbial richness or abundance values of individual OTUs with different environmental factors ( $\mathrm{pH}$, temperature) and chemical data $\left(\mathrm{SO}_{2}, \mathrm{H}_{2} \mathrm{~S}\right)$ was performed in the $\mathrm{R}$ environment. The same software platform was used for generating heatmaps of OTUs showing significant correlations.

For phylogenetic tree construction, a representative OTU was manually selected from the respective subfamily. The $16 \mathrm{~S}$ rRNA gene sequence of each representative OTU was retrieved from SILVA (Pruesse et al., 2007), compiled in a multiple sequence alignment, and used to generate a neighborjoining phylogenetic tree in MEGA 4 (Tamura et al., 2011). Afterward, heatmaps (presence/absence of each representative OTU) were overlaid onto trees in iTOL (Letunic and Bork, 2011). OTUs of represented subfamilies were classified by using the Greengenes (DeSantis et al., 2006) database in combination with the Ribosomal Database Project, and SILVA (DeSantis et al., 2006; Pruesse et al., 2007; Cole et al., 2009). This classification scheme was also repeated later for all archaeal OTUs in the manuscript due to recent classification changes in the literature (Spang et al., 2010).

\section{Results}

\subsection{Microbial population}

Total microbial populations, as measured by the ATP assay, were higher in P1, P2, P3, and L1 samples $\left(\sim 2.0 \times 10^{5}\right.$ RLU/mL) compared to P0 (below detection level) and HS1 samples $\left(5.3 \times 10^{4} \mathrm{RLU} / \mathrm{mL}\right)$. Low ATP content was correlated with the high temperature $\left(>98^{\circ} \mathrm{C}\right)$ of the hot spring samples tested. The viable microbial population based on ATP measurements was as high as $95 \%$ in samples collected from $\mathrm{P} 2\left(\mathrm{pH} 2.9,64^{\circ} \mathrm{C}\right)$. In contrast, this percentage was very low in the $\mathrm{P} 3$ sample $(0.4 \%)$ despite having a similar $\mathrm{pH}$ as P2 (Table 1). The combination of low pH (3.8) and high temperature $\left(100^{\circ} \mathrm{C}\right)$ might have been the reason for the below-detection level of total microbial (ATP assay) and total bacterial (qPCR assay) population in P0 samples. As revealed by ATP assay, qPCR also showed higher bacterial populations for the other samples compared to the P0 and HS1 samples. The percent bacteria (qPCR-based) among the ATPbased total microbial population in all samples collected during this study ranged between $\sim 2 \%$ and $37 \%$ (Table 1).

\subsection{Microbial richness}

An overview of the bacterial richness based on subfamilies in each sample classified by higher taxonomic level 
is depicted in Fig. 2 (presence/absence of a subfamily in each sample). Despite extremely low ATP content in some of the samples $\left(>98^{\circ} \mathrm{C}\right)$ studied (Table 1), the bacterial diversity measurement via the PhyloChip G3 method was successful in all six samples. In total, 1173 bacterial OTUs spanning 576 subfamilies were detected (Supplementary Table S1; Supplementary Data are available online at www .liebertonline.com/ast). All hyperthermophilic hot spring samples had a lower bacterial richness than thermophilic samples (Supplementary Fig. S1). Of the high-temperature samples-P0 (84 OTUs), HS1 (19 OTUs), and L1 (19 OTUs) - only 24 subfamilies were observed; three OTUs were shared between L1 and P0 samples and five OTUs between HS1 and P0. However, hundreds of subfamilies were observed in P1 (529 OTUs), P2 (168 OTUs), and P3 (674 OTUs). Comparatively, P2 was hotter than P1 and P3, both of which of which had greater microbial richness than $\mathrm{P} 2$. Furthermore, the bacterial richness of the P1 and P3 samples, with temperatures $<59^{\circ} \mathrm{C}$, was similar. The distribution of OTUs at higher taxonomic levels was dominated by Firmicutes $(23 \%)$, followed by Betaproteobacteria $(15 \%)$,
Gammaproteobacteria (13\%), Deltaproteobacteria (7\%), Actinobacteria (6\%), Alphaproteobacteria (5\%), Acidobacteria $(5 \%)$, and others. With reference to the archaeal richness, 38 OTUs covering 32 subfamilies were detected including Crenarchaeota (20 OTUs), Euryarchaeota (17 OTUs), and Thaumarchaeota (1 OTU) (Supplementary Table S1). Archaeal OTUs were found in all samples except in P0.

\subsection{Environmental clustering}

Ordination analysis based on NMDS and abundance scores of bacterial OTUs showed that hyperthermophilic hot spring samples clustered apart from thermophilic samples (Fig. 3). This could be attributed to the fact that the bacterial PCR amplicons amplified from hyperthermophilic samples were fewer in quantity $(<100 \mathrm{ng}$ per chip) than samples from thermophilic sites (500 ng per chip). Hence, high-temperature samples exhibited both weaker hybridization intensities and lower abundance scores. However, among the samples with lower temperatures, the bacterial community structure in P1 was comparatively more similar to P3 than P2 (Fig. 3).
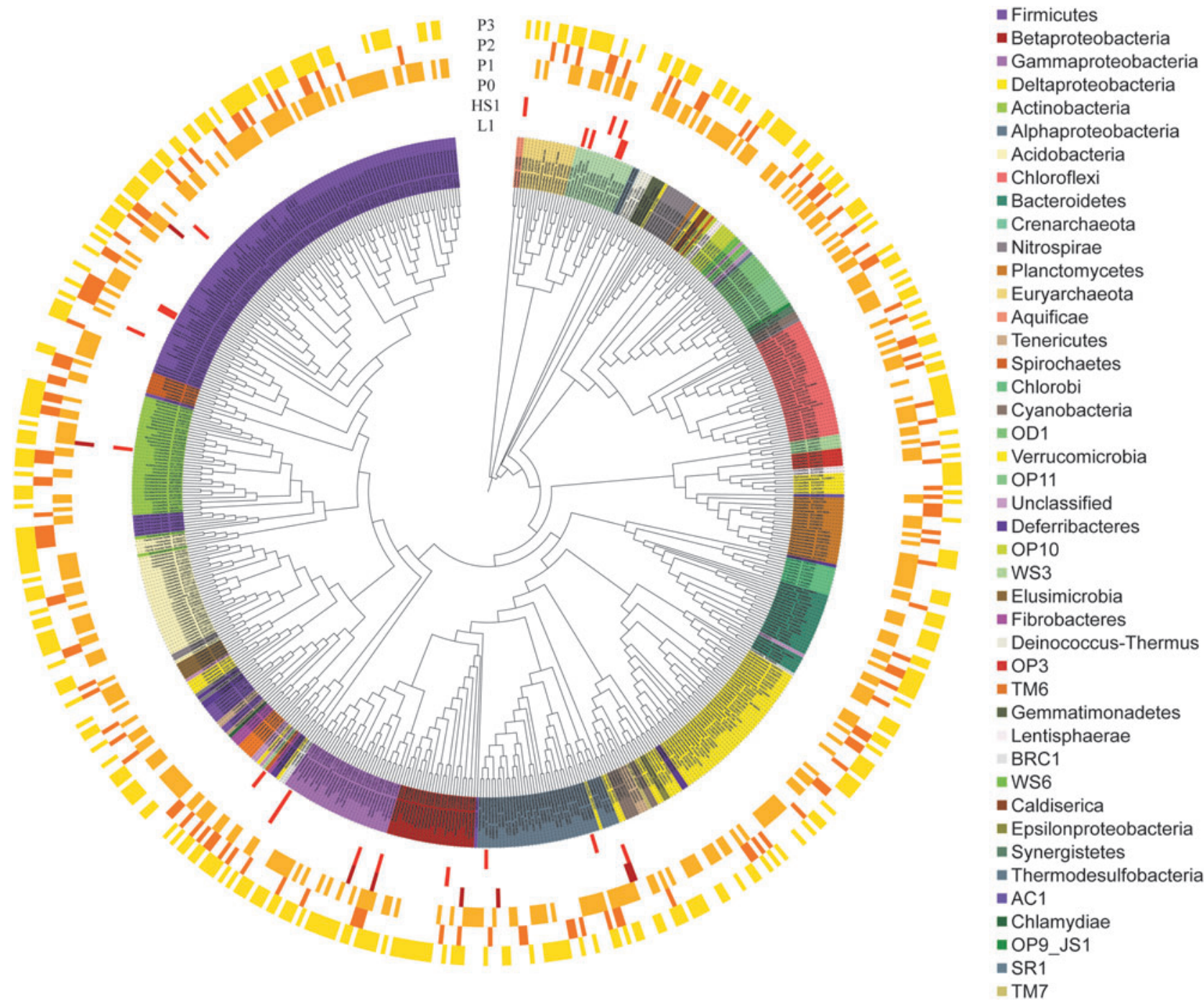

FIG. 2. Phylogenetic neighbor-joining tree of representative OTUs per subfamily detected in the samples. Each node shown in the iTOL circular tree is a representative OTU of a subfamily. Colors indicate the presence of a subfamily in the sample, which are arranged as rings around the tree. The branch lengths in the tree are ignored. 


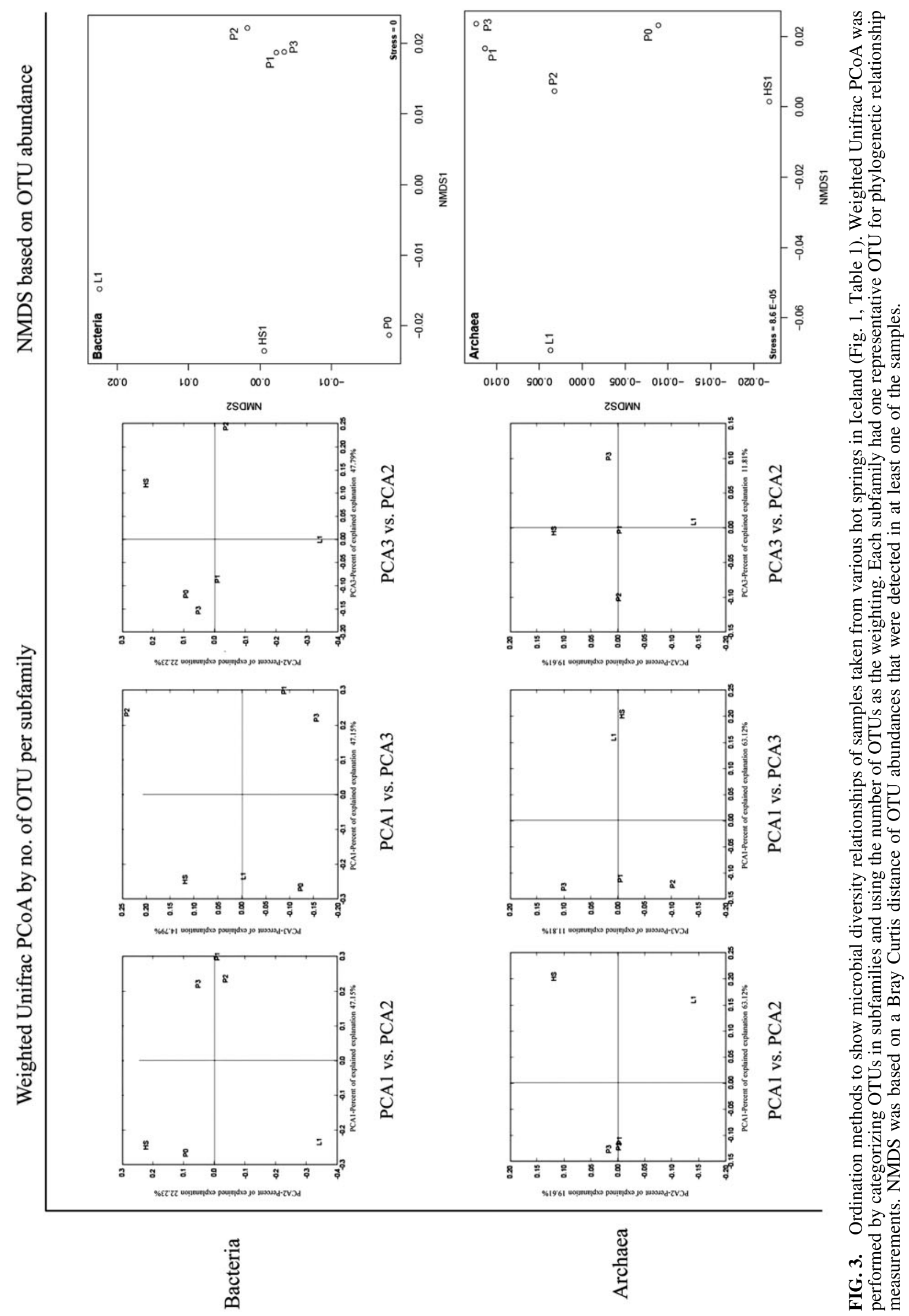


A

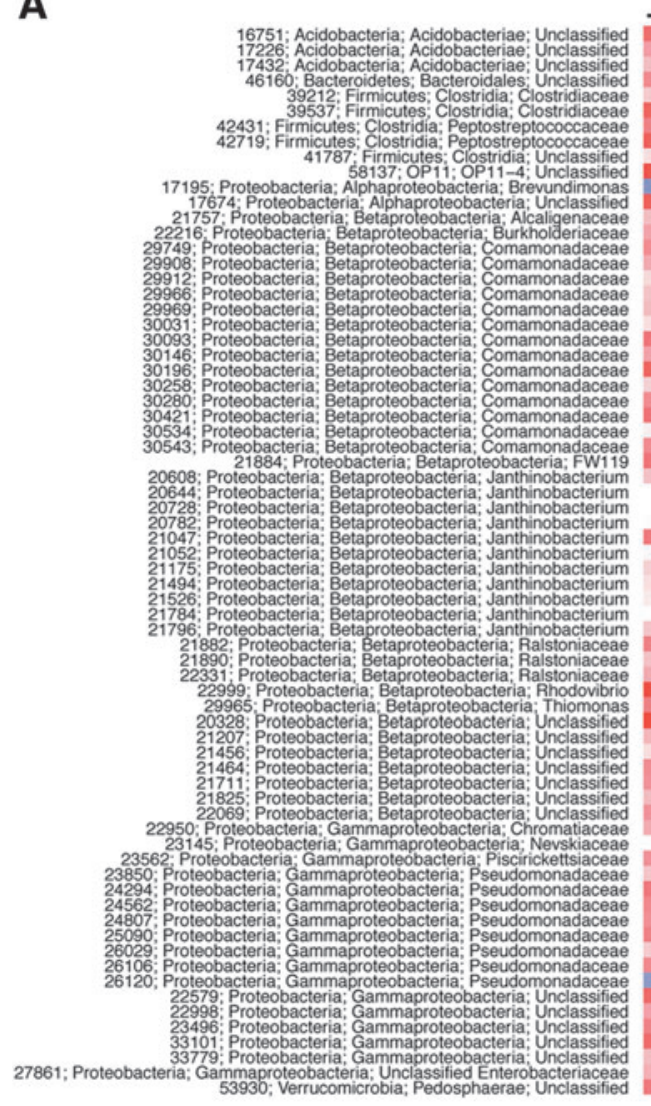

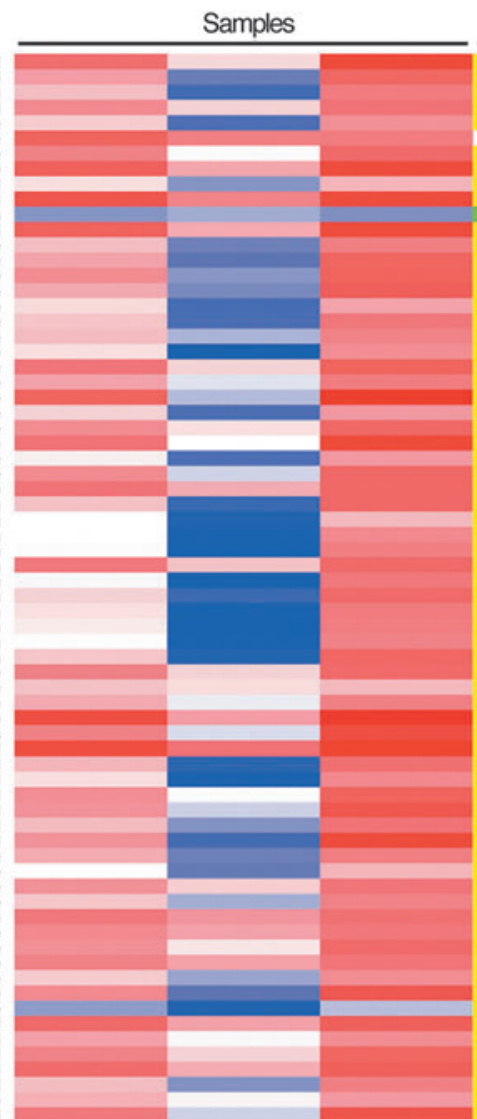

Environmental factors

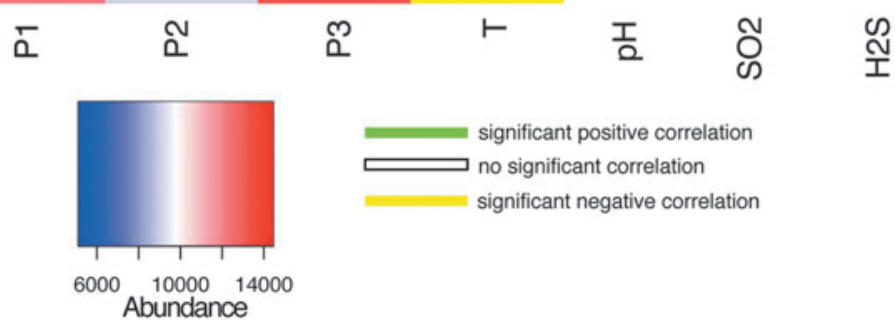

FIG. 4. (Continued).

The NMDS analysis for the archaeal community showed similar environmental clustering as that of bacteria (Fig. 3). With the exception of HS1 and P0, all samples had the same amount of archaeal PCR amplicon used for PhyloChip (100 ng), which allowed us to conclude that the archaeal communities in the P1, P2, and P3 samples were similar to each other but differed greatly from L1. An alternate ordination approach was performed based on the presence or absence of OTUs with one representative per subfamily by using weighted PCoA (Fig. 3). The PCoA-based clustering for the bacterial and archaeal microbial community was in accordance with the relationships observed in NMDS. Sample P0 was not included in PCoA, as no archaeal OTUs were present in this sample (Fig. 3).

\subsection{Correlation of bacterial community with environmental factors}

When bacterial subfamily richness was compared, temperature was the only environmental parameter having a significant correlation (Supplementary Table S2). Considering only thermophilic samples, both environmental clustering methods (NMDS and PCoA) suggested that sample P3 was more related to P1, even though P2 was located between P1 and P3 in the water streamlet. However, it should be noted that P2 was flanked by at least one visible hot spring that emanated into the streamlet (Fig. 1; data not shown), increasing its temperature. To understand the environmental factors that cause this dissimilarity, a Pearson's correlation was applied to the abundance values of individual OTUs that occurred at least once in the $\mathrm{P}$ samples ( $\mathrm{P} 0, \mathrm{P} 1, \mathrm{P} 2$, and $\mathrm{P} 3$ ). Most of the bacteria present (700 out of 1158 OTUs) exhibited a significant negative correlation with temperature ( $p$ value $<0.05$ ), whereas only one of them correlated positively (Caulobacterales-Brevundimonas; Fig. 4A).

Other environmental factors showed significant positive or negative influence on the prevalence of individual OTUs retrieved from P samples: $\mathrm{pH}$ (5 OTUs), $\mathrm{SO}_{2}$ (458 OTUs), and $\mathrm{H}_{2} \mathrm{~S}$ (6 OTUs). However, less amount of bacterial PCR amplicon was hybridized for P0 than for P1, P2, and P3 due 
B

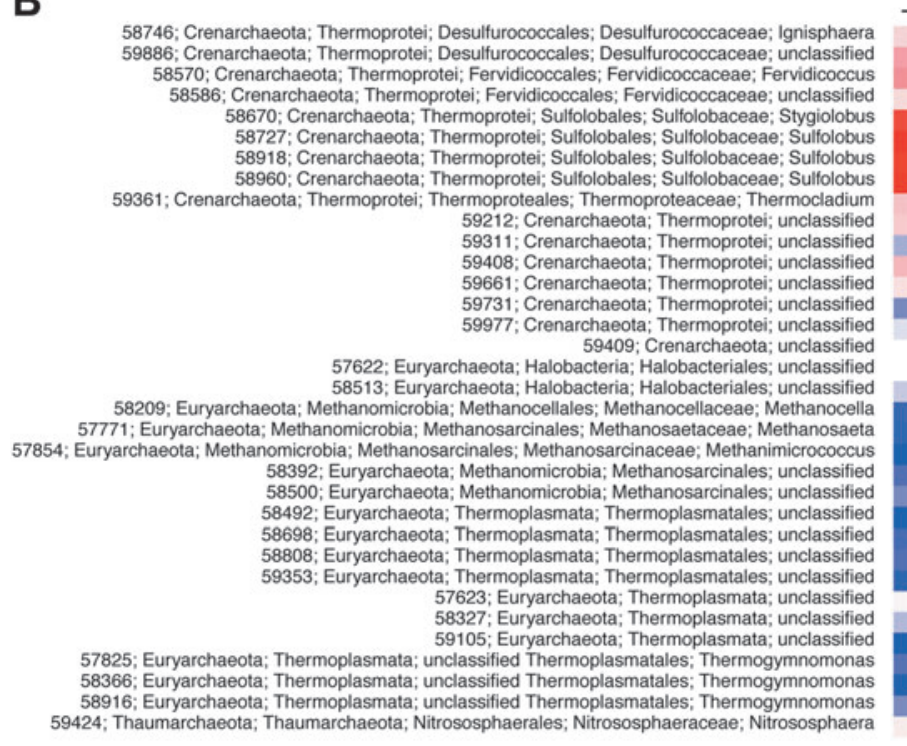

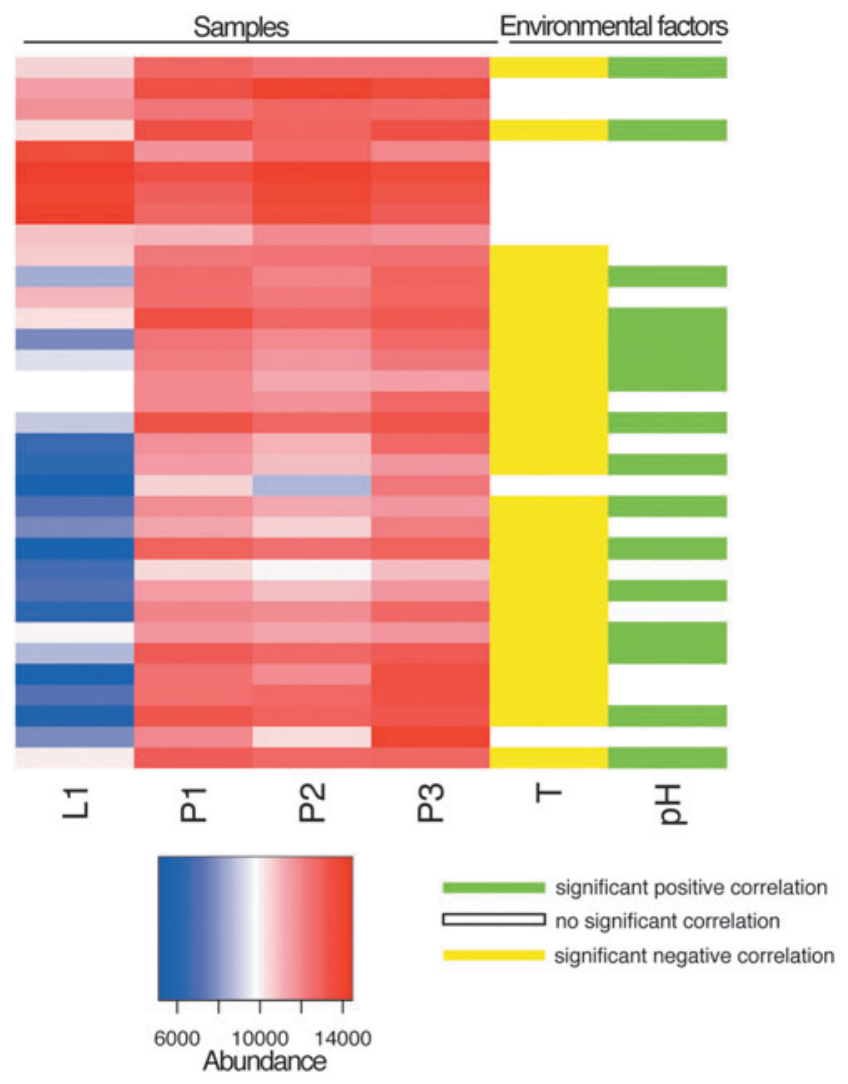

FIG. 4. (A) Heatmap of abundance values of bacterial OTUs detected in the $\mathrm{P}$ system. OTUs that showed a significant correlation between abundance scores in P1, P2, and P3 samples and of the environmental factors measured are shown. Classifications are at the phylum/class level. (B) Heatmap of abundance scores of all archaeal OTUs detected in P1, P2, P3, and L1 samples and their correlation with environmental factors ( $\mathrm{pH}$ and temperature).

to a weak amplification rate, which could confound the correlation analysis performed above. Among the 1158 OTUs detected from the P system, 69 showed a significant correlation with temperature and abundance values when considering P1, P2, and P3 samples only. Additionally, one clostridial OTU correlated positively with $\mathrm{pH}, \mathrm{SO}_{2}$, and $\mathrm{H}_{2} \mathrm{~S}$ (Fig. 4A). As P1 and P3 samples were more similar in environmental clustering methods when compared to P2 (Fig. 3 ), the abundance values were averaged, and the percent increase or decrease in $\mathrm{P} 1$ and $\mathrm{P} 3$ (or P1-P3) compared to P2 was calculated (Supplementary Fig. S2). All bacterial OTUs showed an increase in relative abundance in P1-P3 samples, pointing to a possible absence of novel bacteria in P2 sample $\left(5-7^{\circ} \mathrm{C}\right.$ less). The OTUs representing genetic signatures of Thermodesulfovibrio and Thiomonas were detected in high relative abundance in $\mathrm{P} 1$ and $\mathrm{P} 3$, which might be characteristic to these pools.

\subsection{Correlation of archaeal community with environmental factors}

To clarify the influence of physical and chemical parameters on the distribution of archaea, statistical tests on different community profiling levels were employed. First, ordination analysis of the archaeal population revealed separate grouping of the interconnected $\mathrm{P}$ samples from both $\mathrm{L} 1$ and HS1 (Fig. 3). PERMANOVA testing based on the BrayCurtis index of OTU abundances was completed for P1, P2,
P3, and L1 samples and demonstrated that temperature had a significant influence on the archaeal community structure ( $p$ value $=0.04)$ but $\mathrm{pH}$ did not ( $p$ value $=0.17)$. Similarly, temperature showed a highly significant negative correlation with archaeal richness (Pearson's $r=-0.958, p$ value $=0.003$ ), while $\mathrm{pH}$ was insignificant (Pearson's $r=-0.414, p$ value $=$ 0.414 , Supplementary Table S2). Second, an individual correlation analysis of each archaeal OTU with temperature and $\mathrm{pH}$, respectively, was performed. Hybridization intensities of OTUs that were present in at least one of the above-mentioned samples were individually correlated with environmental factors across these samples. OTUs with significant correlation values were selected to construct a heatmap presenting their relative difference in hybridization intensity, correlation with the environmental factor, and their taxonomic affiliation (Fig. 4). In general, when archaeal OTU abundances of P1, P2, P3, and L1 samples were computed, $74 \%$ correlated negatively with temperature, and $47 \%$ correlated positively with $\mathrm{pH}$ (Fig. 4B). For instance, genetic signatures of mesophilic archaea, such as Nitrososphaera-related OTUs, were more abundant at higher $\mathrm{pH}$ and lower temperatures.

\section{Discussion}

There are numerous technological problems (sample collection, processing, and detection) that have precluded a comprehensive microbial census of "low biomass" 
extreme environments such as hot springs. A previously favored technique to describe the microbial composition of hot springs at a molecular level was the cloning and Sanger sequencing method (Marteinsson et al., 2001a, 2001b; Hobel et al., 2005; Kvist et al., 2007). Many publications show the limitations of this technique, in particular, its low sensitivity due to the small amount of clones sequenced per sample (La Duc et al., 2009; Hazen et al., 2010). In a previous study, Thermotogales or Thermodesulfobacteria taxa were not detected from the samples of Hveragerði wastewater drain $(\sim \mathrm{pH} 9)$ or from Geysir sites $\left(70-83^{\circ} \mathrm{C}, \mathrm{pH}\right.$ 9) (Tobler and Benning, 2011). However, the present study identified Thermodesulfobacteria within the thermophilic P1, P2, and P3 systems, which corroborates that the PhyloChip G3 microarray is one of the most sensitive technologies among next-generation methods available for comprehensively measuring the microbial census (Hazen et al., 2010; Venkateswaran et al., 2012). The limit of detection for PhyloChip G3 is $2 \mathrm{p} M$ of generated $16 \mathrm{~S}$ rRNA gene amplicons. Even though some of the samples $\left(>98^{\circ} \mathrm{C}\right.$ ) studied were extremely low in ATP content (a proxy for microbial biomass), the microbial diversity measurement via PhyloChip G3 method was successful in all samples examined.

Compared to other terrestrial habitats such as soil, where PhyloChip G3 analysis was able to detect more than 33,000 different OTUs (Mendes et al., 2011), the samples reported here contained a very restricted community profile (1173 OTUs) that reflects the extreme nature of the environments studied. Supporting our assumption that hot springs of this nature are low in biomass, a recently concluded PhyloChipbased study reported the presence of only 4882 OTUs associated with a Chinese hot spring (Briggs et al., 2013). As documented previously in Thailand's Bor Khlueng neutral $\mathrm{pH}$ hot spring systems $\left(50-57^{\circ} \mathrm{C}\right)$, members of major phyla were well represented in the P1, P2, and P3 samples (Kanokratana et al., 2004). Similarly, bacteria of high abundance (Aquificales, Nitrospira, and Thermodesulfobacterium) detected during this study were also shown to be major constituents in nearby sulfide-rich and silica-depositing Icelandic hot springs that were alkaliphilic ( $\mathrm{pH} \mathrm{8-10)}$ and thermophilic $\left(\sim 65^{\circ} \mathrm{C}\right)$ (Tobler and Benning, 2011), as well as in other silica-precipitating hot springs in New Zealand (Childs et al., 2008), Japan (Yamamoto et al., 1998), and the USA (Blank et al., 2002; Wilson et al., 2008). In Hveragerði wastewater drain sample with a temperature of about $70^{\circ} \mathrm{C}$, Aquificae represented about $11 \%$ of OTUs (Tobler and Benning, 2011). Though no Aquificae OTUs were detected in $\mathrm{P0}\left(100^{\circ} \mathrm{C}\right), 16 \%, 5.3 \%$, and $4.8 \%$ of all OTUs were members of Aquificae in $\mathrm{L} 1\left(98^{\circ} \mathrm{C}\right)$, $\mathrm{HS} 1\left(98^{\circ} \mathrm{C}\right)$, and $\mathrm{P} 2\left(64^{\circ} \mathrm{C}\right)$, respectively. Therefore, with the exception of $\mathrm{P} 0$, hot springs sampled with temperatures above $60^{\circ} \mathrm{C}$ showed greater percentages of Aquificae OTUs in our study. These observations are in agreement with earlier studies that suggested that chemolithotrophic organisms, belonging to the order Aquificales, dominate the bacterial communities in hot spring geothermal waters (Flores et al., 2008; Boomer et al., 2009).

In an independent parallel study, the same samples collected from P1, P2, and P3 pools were subjected to the denaturing gradient gel electrophoresis (DGGE) method; and the presence of Alphaproteobacteria, Betaproteobacteria, Actinobacteria, Bacilli, Clostridia, Aquificae, and unclassified bacteria was reported (Marteinsson et al., 2013). However, PhyloChip G3 analysis revealed the presence of not only those bacterial taxa detected via DGGE but also additional lineages (Fig. 2, Supplementary Table S1) not previously detected in other hot spring systems (Hreggvidsson et al., 2006; Flores et al., 2008; Koskinen et al., 2008). It is also worth mentioning that DGGE bands were not observed in hyperthermophilic P0, L1, or HS1 samples (Marteinsson et al., 2013), whereas PhyloChip G3 revealed the presence of several microbial taxa (Fig. 2, Supplementary Table S1).

While temperature was the key environmental factor of all parameters measured, $\mathrm{pH}$ might have dictated the abundance of acidophilic bacteria. Also, the acidic nature of this hot spring system influenced its microbial diversity and structure. For instance, 84 OTUs dominated by Gammaproteobacteria were observed in the hot $\mathrm{P} 0$ sample $\left(100^{\circ} \mathrm{C}\right)$ where $\mathrm{pH}$ was 3.8 , but only 19 OTUs were observed in a similarly high-temperature but neutral $\mathrm{pH}$ sample (HS1). Most of the identified OTUs belonging to the acidophilic bacteria were from the P1, P2, and P3 systems. The acidophilic taxa classified during this study were either identified as Acidobacteria (56 OTUs) or belong to the members of Alphaproteobacteria (59 OTUs) and Nitrospirae (15 OTUs), whose sequences were previously retrieved from acidophilic environments. Nitrospira-related OTUs were found in the P1, P2, and P3 samples, whose presence was confirmed previously in a Hveragerði wastewater drain $(\sim \mathrm{pH} 9)(\mathrm{To}-$ bler and Benning, 2011). Nitrospira was shown to be tolerant of low ( 2.9) and moderately high ( 9) $\mathrm{pH}$ possibly due to microhabitats in which other microbes provide a $\mathrm{pH}$ niche for these bacteria to survive (Altmann et al., 2003). Similarly, members of the Nitrospira genus isolated from a hot spring in Nevada, USA, demonstrated a maximum growth temperature slightly above $63^{\circ} \mathrm{C}$ (similar to P2) (Lefèvre et al., 2010). Thus, the presence of Nitrospira in the P1, P2, and P3 systems might be due to their preference to a thermophilic condition, along with the adaptation to the environment or coexisting microbes that might alter the $\mathrm{pH}$ of the microhabitat. In addition to Nitrospira, Thermus and Bacillus were previously found to be dominant microorganisms in hot spring geothermal waters (Hreggvidsson et al., 2006).

Past studies have shown that Archaea flourish in $\mathrm{pH}$, temperature, salinity, and oxygen-level extremes (Woese et al., 1990; Kristjánsson and Hreggvidsson, 1995; Blochl et al., 1997; Chen et al., 2005; Stetter, 2006). However, recent studies have detected and cultivated many mesophilic and non-extremophilic archaea (de la Torre et al., 2008; Tourna et al., 2011), members of this domain are still largely unknown. It was reported that ammonia-oxidizing archaea like Nitrososphaera occur at moderate temperatures and were abundant in soil under both neutral $\mathrm{pH}$ conditions and thermophilic conditions (Hatzenpichler et al., 2008; Tourna et al., 2011; Spang et al., 2012). Consequently, an enrichment of these archaea at lower temperatures and higher $\mathrm{pH}$ was in accordance with their physical and chemical properties. In contrast, three OTUs of the Sulfolobales (Stygiolobus sp. and Sulfolobus sp.) did not correlate negatively with temperature or positively with $\mathrm{pH}$. For this archaeal order, a trend was observed in lieu of a significant relationship (Pearson's $r=0.92$ for OTU 58670, $p$ value 0.08); the Sulfolobales were enriched (higher abundance 
values) in the L1 sample, which had higher temperature and lower $\mathrm{pH}$. These archaea maintain low intracellular $\mathrm{pH}$ to keep Fe-S enzymes operative in central metabolic and bioenergetic pathways (Schafer et al., 1999; Iwasaki and Oshima, 2001). Previous studies have reported Sulfolobales in hot springs at low $\mathrm{pH}$ levels, where they thrive chemolithotrophically by oxidizing sulfur (Shivvers and Brock, 1973; Brock, 1978; Kvist et al., 2007). In contrast to the enrichment of the Sulfolobales, members of the methanogens showed a positive correlation of abundance with increasing $\mathrm{pH}$. It is generally believed that a $\mathrm{pH}$ below 5 can inhibit the methanogenic activity in anaerobic biological systems (Kim et al., 2004), but all samples included in the archaeal correlation analysis had a $\mathrm{pH}$ below 3.5. Their presence in these systems may be attributed to microhabitats provided by other microorganisms.

It has been demonstrated that the microbial community structure correlates with environmental geochemical parameters, such as temperature, salinity, $\mathrm{pH}$, energy source availability, and geographical isolation (Petursdottir et al., 2009). Likewise, when physical, chemical, and biological parameters of thermophilic but neutral $\mathrm{pH}$ Icelandic hot springs were characterized, temperature, salinity, and sinter growth rate were found to be the primary regulators of microbial abundance (Tobler and Benning, 2011; Tobler et al., 2008). Since only microbial density and abundance were characterized in previous Icelandic hot spring studies (Tobler et al., 2008), a more detailed look at the microbial diversity is necessary to understand the influence of the environmental factors measured. Results of this study provide evidence that temperature was the key abiotic factor responsible for microbial community dynamics, while $\mathrm{pH}$, $\mathrm{H}_{2} \mathrm{~S}$, and $\mathrm{SO}_{2}$ influenced the abundance of specific microbial groups.

\section{Conclusion}

The combination of multiple analyses improves our ability to accurately assess the microbial structure and dynamics of low-biomass extreme environments. Metadata collection (physical and chemical attributes), microbial population estimation (ATP and qPCR assays), and microbial richness and abundance measurement (PhyloChip G3) carried out during this study enabled us to better understand the microbial population dynamics of the Hveragerði Icelandic hot spring system. Overall, this study, along with others, revealed that the microbial community structure correlates well with specific physical-chemical and geochemical parameters, including temperature, salinity, $\mathrm{pH}$, and energy source availability. The Hverageroi Icelandic hot spring system may harbor sources of new bioactive compounds as well as novel microbial species and may merit future diversity mapping with emerging novel molecular technologies.

\section{Acknowledgments}

Part of the research described in this study was carried out at the Jet Propulsion Laboratory, California Institute of Technology, under contract with the National Aeronautics and Space Administration. A. Probst's contribution was supported by the German National Academic Foundation
(Studienstiftung des deutschen Volkes). J. Krebs's participation was funded by a Caltech Amgen Scholars Fellowship awarded in 2011. The authors are grateful to the Coordination Action for Research Activities on life in Extreme Environments (CAREX) project funded by the European Commission. A special thanks to N. Walter, European Science Federation, for supporting P. Vaishampayan's travel to Iceland. We are also thankful to all the participants for their assistance in the Icelandic CAREX fieldwork.

\section{Abbreviations}

ATP, adenosine triphosphate; DGGE, denaturing gradient gel electrophoresis; NMDS, non-metric multidimensional scaling; OTUs, operational taxonomic units; PCoA, principal component analysis; qPCR, quantitative polymerase chain reaction; RLU, relative light unit; rRNA, ribosomal ribonucleic acid.

\section{References}

Altmann, D., Stief, P., Amann, R., De Beer, D., and Schramm, A. (2003) In situ distribution and activity of nitrifying bacteria in freshwater sediment. Environ Microbiol 5:798-803.

Barns, S.M., Delwiche, C.F., Palmer, J.D., and Pace, N.R. (1996) Perspectives on archaeal diversity, thermophily and monophyly from environmental rRNA sequences. Proc Natl Acad Sci USA 93:9188-9193.

Barth, T.F.W. (1950) Volcanic Geology, Hot Springs and Geysers of Iceland, Carnegie Institution of Washington, Washington, DC.

Blank, C.E., Cady, S.L., and Pace, N.R. (2002) Microbial composition of near-boiling silica-depositing thermal springs throughout Yellowstone National Park. Appl Environ Microbiol 68:5123-5135.

Blochl, E., Rachel, R., Burggraf, S., Hafenbradl, D., Jannasch, H.W., and Stetter, K.O. (1997) Pyrolobus fumarii, gen. and sp. nov., represents a novel group of archaea, extending the upper temperature limit for life to 113 degrees C. Extremophiles 1:14-21.

Bohorquez, L.C., Delgado-Serrano, L., Lopez, G., OsorioForero, C., Klepac-Ceraj, V., Kolter, R., Junca, H., Baena, S., and Zambrano, M.M. (2012) In-depth characterization via complementing culture-independent approaches of the microbial community in an acidic hot spring of the Colombian Andes. Microb Ecol 63:103-115.

Boomer, S.M., Noll, K.L., Geesey, G.G., and Dutton, B.E. (2009) Formation of multilayered photosynthetic biofilms in an alkaline thermal spring in Yellowstone National Park, Wyoming. Appl Environ Microbiol 75:2464-2475.

Briggs, B.R., Brodie, E.L., Tom, L.M., Dong, H., Jiang, H., Huang, Q., Wang, S., Hou, W., Wu, G., Huang, L., Hedlund, B.P., Zhang, C., Dijkstra, P., and Hungate, B.A. (2013) Seasonal patterns in microbial communities inhabiting the hot springs of Tengchong, Yunnan Province, China. Environ Microbiol doi:10.1111/1462-2920.12311.

Brock, T.D. (1978) Thermophilic Microorganisms and Life at High Temperatures, Springer-Verlag, New York.

Brodie, E.L., DeSantis, T.Z., Joyner, D.C., Baek, S.M., Larsen, J.T., Andersen, G.L., Hazen, T.C., Richardson, P.M., Herman, D.J., Tokunaga, T.K., Wan, J.M., and Firestone, M.K. (2006) Application of a high-density oligonucleotide microarray approach to study bacterial population dynamics during uranium reduction and reoxidation. Appl Environ Microbiol 72:6288-6298. 
Chen, L., Brügger, K., Skovgaard, M., Redder, P., She, Q., Torarinsson, E., Greve, B., Awayez, M., Zibat, A., Klenk, H.-P., and Garrett, R.A. (2005) The genome of Sulfolobus acidocaldarius, a model organism of the Crenarchaeota. J Bacteriol 187:4992-4999.

Childs, A., Mountain, B., O'Toole, R., and Stott, M. (2008) Relating microbial community and physicochemical parameters of a hot spring: Champagne Pool, Wai-o-tapu, New Zealand. Geomicrobiol J 25:441-453.

Cole, J.R., Wang, Q., Cardenas, E., Fish, J., Chai, B., Farris, R.J., Kulam-Syed-Mohideen, A.S., McGarrell, D.M., Marsh, T., Garrity, G.M., and Tiedje, J.M. (2009) The Ribosomal Database Project: improved alignments and new tools for rRNA analysis. Nucleic Acids Res 37:D141-D145.

Cooper, M., La Duc, M.T., Probst, A., Vaishampayan, P., Stam, C., Benardini, J.N., Piceno, Y.M., Andersen, G.L., and Venkateswaran, K. (2011) Comparison of innovative molecular approaches and standard spore assays for assessment of surface cleanliness. Appl Environ Microbiol 77:5438-5444.

de la Torre, J.R., Walker, C.B., Ingalls, A.E., Konneke, M., and Stahl, D.A. (2008) Cultivation of a thermophilic ammonia oxidizing archaeon synthesizing crenarchaeol. Environ Microbiol 10:810-818.

DeSantis, T.Z., Hugenholtz, P., Larsen, N., Rojas, M., Brodie, E.L., Keller, K., Huber, T., Dalevi, D., Hu, P., and Andersen, G.L. (2006) Greengenes, a chimera-checked 16S rRNA gene database and workbench compatible with ARB. Appl Environ Microbiol 72:5069-5072.

DeSantis, T.Z., Brodie, E.L., Moberg, J.P., Zubieta, I.X., Piceno, Y.M., and Andersen, G.L. (2007) High-density universal $16 \mathrm{~S}$ rRNA microarray analysis reveals broader diversity than typical clone library when sampling the environment. Microb Ecol 53:371-383.

Flores, G.E., Liu, Y., Ferrera, I., Beveridge, T.J., and Reysenbach, A.L. (2008) Sulfurihydrogenibium kristjanssonii sp. nov., a hydrogen- and sulfur-oxidizing thermophile isolated from a terrestrial Icelandic hot spring. Int J Syst Evol Microbiol 58:1153-1158.

Hamady, M., Lozupone, C., and Knight, R. (2010) Fast UniFrac: facilitating high-throughput phylogenetic analyses of microbial communities including analysis of pyrosequencing and PhyloChip data. ISME J 4:17-27.

Hatzenpichler, R., Lebedeva, E.V., Spieck, E., Stoecker, K., Richter, A., Daims, H., and Wagner, M. (2008) A moderately thermophilic ammonia-oxidizing crenarchaeote from a hot spring. Proc Natl Acad Sci USA 105:2134-2139.

Hazen, T.C., Dubinsky, E.A., DeSantis, T.Z., Andersen, G.L., Piceno, Y.M., Singh, N., Jansson, J.K., Probst, A., Borglin, S.E., Fortney, J.L., Stringfellow, W.T., Bill, M., Conrad, M.E., Tom, L.M., Chavarria, K.L., Alusi, T.R., Lamendella, R., Joyner, D.C., Spier, C., Baelum, J., Auer, M., Zemla, M.L., Chakraborty, R., Sonnenthal, E.L., D'Haeseleer, P., Holman, H.Y., Osman, S., Lu, Z., Van Nostrand, J.D., Deng, Y., Zhou, J., and Mason, O.U. (2010) Deep-sea oil plume enriches indigenous oil-degrading bacteria. Science 330:204-208.

Hobel, C.F., Marteinsson, V.T., Hreggvidsson, G.O., and Kristjansson, J.K. (2005) Investigation of the microbial ecology of intertidal hot springs by using diversity analysis of 16S rRNA and chitinase genes. Appl Environ Microbiol 71:2771-2776.

Hreggvidsson, G.O., Skirnisdottir, S., Smit, B., Hjorleifsdottir, S., Marteinsson, V.T., Petursdottir, S., and Kristjansson, J.K. (2006) Polyphasic analysis of Thermus isolates from geothermal areas in Iceland. Extremophiles 10:563-575.
Hugenholtz, P., Pitulle, C., Hershberger, K.L., and Pace, N.R. (1998) Novel division level bacterial diversity in a Yellowstone hot spring. J Bacteriol 180:366-376.

Iwasaki, T. and Oshima, T. (2001) Ferredoxin and related enzymes from Sulfolobus. Methods Enzymol 334:3-22.

Kanokratana, P., Chanapan, S., Pootanakit, K., and Eurwilaichitr, L. (2004) Diversity and abundance of Bacteria and Archaea in the Bor Khlueng hot spring in Thailand. J Basic Microbiol 44:430-444.

Kim, I.S., Hwang, M.H., Jang, N.J., Hyun, S.H., and Lee, S.T. (2004) Effect of low pH on the activity of hydrogen utilizing methanogen in bio-hydrogen process. Int J Hydrogen Energy 29:1133-1140.

Koskinen, P.E., Lay, C.H., Puhakka, J.A., Lin, P.J., Wu, S.Y., Orlygsson, J., and Lin, C.Y. (2008) High-efficiency hydrogen production by an anaerobic, thermophilic enrichment culture from an Icelandic hot spring. Biotechnol Bioeng 101:665-678.

Kristjánsson, J.K. and Hreggvidsson, G.O. (1995) Ecology and habitats of extremophiles. World J Microbiol Biotechnol $11: 17-25$.

Kublanov, I.V., Perevalova, A.A., Slobodkina, G.B., Lebedinsky, A.V., Bidzhieva, S.K., Kolganova, T.V., Kaliberda, E.N., Rumsh, L.D., Haertle, T., and Bonch-Osmolovskaya, E.A. (2009) Biodiversity of thermophilic prokaryotes with hydrolytic activities in hot springs of Uzon Caldera, Kamchatka (Russia). Appl Environ Microbiol 75:286-291.

Kvist, T., Ahring, B.K., and Westermann, P. (2007) Archaeal diversity in Icelandic hot springs. FEMS Microbiol Ecol 59:71-80.

Kwan, K., Cooper, M., La Duc, M.T., Vaishampayan, P., Stam, C., Benardini, J.N., Scalzi, G., Moissl-Eichinger, C., and Venkateswaran, K. (2011) Evaluation of procedures for the collection, processing, and analysis of biomolecules from low-biomass surfaces. Appl Environ Microbiol 77: 2943-2953.

La Duc, M.T., Dekas, A., Osman, S., Moissl, C., Newcombe, D., and Venkateswaran, K. (2007) Isolation and characterization of bacteria capable of tolerating the extreme conditions of clean room environments. Appl Environ Microbiol 73:2600-2611.

La Duc, M.T., Osman, S., Vaishampayan, P., Piceno, Y., Andersen, G., Spry, J.A., and Venkateswaran, K. (2009) Comprehensive census of bacteria in clean rooms by using DNA microarray and cloning methods. Appl Environ Microbiol 75:6559-6567.

Lefèvre, C.T., Abreu, F., Schmidt, M.L., Lins, U., Frankel, R.B., Hedlund, B.P., and Bazylinski, D.A. (2010) Moderately thermophilic magnetotactic bacteria from hot springs in Nevada. Appl Environ Microbiol 76:3740-3743.

Letunic, I. and Bork, P. (2011) Interactive tree of life v2: online annotation and display of phylogenetic trees made easy. Nucleic Acids Res 39:W475-W478.

Marteinsson, V., Vaishampayan, P., Kviderova, J., Mapelli, F., Medori, M., Calfapietra, C., Aguilera, A., Hamisch, D., Reynisson, E., Magnússon, S., Marasco, R., Borin, S., CalzadaDiaz, A., Souza-Egipsy, V., González-Toril, E., Amils, R., Elster, J., and Hänsch, R. (2013) A laboratory of the extremophiles: Iceland CAREX field campaign. Life 3:211-233. Marteinsson, V.T., Hauksdottir, S., Hobel, C.F., Kristmannsdottir, H., Hreggvidsson, G.O., and Kristjansson, J.K. (2001a) Phylogenetic diversity analysis of subterranean hot springs in Iceland. Appl Environ Microbiol 67:4242-4248.

Marteinsson, V.T., Kristjansson, J.K., Kristmannsdottir, H., Dahlkvist, M., Saemundsson, K., Hannington, M., Pet- 
ursdottir, S.K., Geptner, A., and Stoffers, P. (2001b) Discovery and description of giant submarine smectite cones on the seafloor in Eyjafjordur, northern Iceland, and a novel thermal microbial habitat. Appl Environ Microbiol 67: 827-833.

Martin, W., Baross, J., Kelley, D., and Russell, M.J. (2008) Hydrothermal vents and the origin of life. Nat Rev Microbiol 6:805-814.

Mendes, R., Kruijt, M., de Bruijn, I., Dekkers, E., van der Voort, M., Schneider, J.H., Piceno, Y.M., DeSantis, T.Z., Andersen, G.L., Bakker, P.A., and Raaijmakers, J.M. (2011) Deciphering the rhizosphere microbiome for disease-suppressive bacteria. Science 332:1097-1100.

Mori, K., Sunamura, M., Yanagawa, K., Ishibashi, J., Miyoshi, Y., Iino, T., Suzuki, K., and Urabe, T. (2008) First cultivation and ecological investigation of a bacterium affiliated with the candidate phylum OP5 from hot springs. Appl Environ Microbiol 74:6223-6229.

Pace, N.R. (1997) A molecular view of microbial diversity and the biosphere. Science 276:734-740.

Petursdottir, S.K., Bjornsdottir, S.H., Hreggvidsson, G.O., Hjorleifsdottir, S., and Kristjansson, J.K. (2009) Analysis of the unique geothermal microbial ecosystem of the Blue Lagoon. FEMS Microbiol Ecol 70:425-432.

Pruesse, E., Quast, C., Knittel, K., Fuchs, B.M., Ludwig, W., Peplies, J., and Glockner, F.O. (2007) SILVA: a comprehensive online resource for quality checked and aligned ribosomal RNA sequence data compatible with ARB. Nucleic Acids Res 35:7188-7196.

Reysenbach, A.L., Wickham, G.S., and Pace, N.R. (1994) Phylogenetic analysis of the hyperthermophilic pink filament community in Octopus Spring, Yellowstone National Park. Appl Environ Microbiol 60:2113-2119.

Schafer, G., Engelhard, M., and Muller, V. (1999) Bioenergetics of the archaea. Microbiol Mol Biol Rev 63:570-620.

Shima, S. and Suzuki, K.-I. (1993) Hydrogenobacter acidophilus sp. nov., a thermoacidophilic, aerobic, hydrogenoxidizing bacterium requiring elemental sulfur for growth. Int J Syst Bacteriol 43:703-708.

Shivvers, D.W. and Brock, T.D. (1973) Oxidation of elemental sulfur by Sulfolobus acidocaldarius. J Bacteriol 114: 706-710.

Skírnisdóttir, S., Hreggvidsson, G.O., Hjörleifsdottir, S., Marteinsson, V.T., Petursdottir, S.K., Holst, O., and Kristjansson, J.K. (2000) Influence of sulfide and temperature on species composition and community structure of hot spring microbial mats. Appl Environ Microbiol 66:2835-2841.

Spang, A., Hatzenpichler, R., Brochier-Armanet, C., Rattei, T., Tischler, P., Spieck, E., Streit, W., Stahl, D.A., Wagner, M., and Schleper, C. (2010) Distinct gene set in two different lineages of ammonia-oxidizing archaea supports the phylum Thaumarchaeota. Trends Microbiol 18:331-340.

Spang, A., Poehlein, A., Offre, P., Zumbragel, S., Haider, S., Rychlik, N., Nowka, B., Schmeisser, C., Lebedeva, E.V., Rattei, T., Bohm, C., Schmid, M., Galushko, A., Hatzenpichler, R., Weinmaier, T., Daniel, R., Schleper, C., Spieck, E., Streit, W., and Wagner, M. (2012) The genome of the ammonia-oxidizing Candidatus Nitrososphaera gargensis: insights into metabolic versatility and environmental adaptations. Environ Microbiol 14:3122-3145.

Stahl, D.A., Lane, D.J., Olsen, G.J., and Pace, N.R. (1985) Characterization of a Yellowstone hot spring microbial community by 5S rRNA sequences. Appl Environ Microbiol 49:1379-1384.
Stetter, K.O. (1982) Ultrathin mycelia-forming organisms from submarine volcanic areas having an optimum growth temperature of $105^{\circ} \mathrm{C}$. Nature 300:258-260.

Stetter, K.O. (2006) Hyperthermophiles in the history of life. Philos Trans $R$ Soc Lond B Biol Sci 361:1837-1842; discussion 1842-1843.

Stetter, K.O., Thomm, M., Winter, J., Wildgruber, G., Huber, H., Zillig, W., Jané-Covic, D., König, H., Palm, P., and Wunderl, S. (1981) Methanothermus fervidus sp. nov., a novel extremely thermophilic methanogen isolated from an Icelandic hot spring. Zbl Bakt Hyg, I Abt Orig 2:166-178.

Tamura, K., Peterson, D., Peterson, N., Stecher, G., Nei, M., and Kumar, S. (2011) MEGA5: molecular evolutionary genetics analysis using maximum likelihood, evolutionary distance, and maximum parsimony methods. Mol Biol Evol 28:2731-2739.

Tobler, D.J. and Benning, L.G. (2011) Bacterial diversity in five Icelandic geothermal waters: temperature and sinter growth rate effects. Extremophiles 15:473-485.

Tobler, D.J., Stefánsson, A., and Benning, L.G. (2008) In-situ grown silica sinters in Icelandic geothermal areas. Geobiology 6:481-502.

Tourna, M., Stieglmeier, M., Spang, A., Konneke, M., Schintlmeister, A., Urich, T., Engel, M., Schloter, M., Wagner, M., Richter, A., and Schleper, C. (2011) Nitrososphaera viennensis, an ammonia oxidizing archaeon from soil. Proc Natl Acad Sci USA 108:8420-8425.

Venkateswaran, K., Hattori, N., La Duc, M.T., and Kern, R. (2003) ATP as a biomarker of viable microorganisms in clean-room facilities. J Microbiol Methods 52:367-377.

Venkateswaran, K., La Duc, M.T., and Vaishampayan, P. (2012) Genetic Inventory Task: Final Report, JPL Publication 12-12, Jet Propulsion Laboratory, California Institute of Technology, Pasadena, CA.

Ward, D.M., Weller, R., and Bateson, M.M. (1990) 16S rRNA sequences reveal numerous uncultured microorganisms in a natural community. Nature 345:63-65.

Wilson, M.S., Siering, P.L., White, C.L., Hauser, M.E., and Bartles, A.N. (2008) Novel archaea and bacteria dominate stable microbial communities in North America's largest hot spring. Microb Ecol 56:292-305.

Woese, C.R., Kandler, O., and Wheelis, M.L. (1990) Towards a natural system of organisms: proposal for the domains Archaea, Bacteria, and Eucarya. Proc Natl Acad Sci USA 87: 4576-4579.

Yamamoto, H., Hiraishi, A., Kato, K., Chiura, H.X., Maki, Y., and Shimizu, A. (1998) Phylogenetic evidence for the existence of novel thermophilic bacteria in hot spring sulfur-turf microbial mats in Japan. Appl Environ Microbiol 64:1680-1687.

Address correspondence to: Parag Vaishampayan California Institute of Technology Jet Propulsion Laboratory Biotechnology and Planetary Protection Group M/S 89-108 4800 Oak Grove Dr. Pasadena, CA 91109

E-mail: vaishamp@jpl.nasa.gov

Submitted 31 March 2013 Accepted 28 January 2014 